\title{
An Analysis of Endophoric Reference Cohesion Devices in Mark Zuckerberg Biography
}

\author{
Melani Siti Khalifah $^{1}$, Juan Carlina Wibowo ${ }^{2}$, Cynantia Rahmijati ${ }^{3}$ \\ ${ }^{1}$ IKIP SILIWANGI \\ ${ }^{2}$ IKIP SILIWANGI \\ ${ }^{3}$ IKIP SILIWANGI \\ ${ }^{1}$ Melanisiti.k13@gmail.com, ${ }^{2}$ Juancarlina20@gmail.com,${ }^{3}$ Cynantiarachmijati@ikipsiliwangi.ac.id
}

\begin{abstract}
The aim of the research is to find out endophoric references in Mark Zuckerberg biography and the relationship between discourse analysis and pragmatic. The research used descriptive qualitative research design. The data obtained from Mark Zuckerberg biography written by the biography website. The data are analyzed using Halliday \& Hasan's theory (1976) of reference cohesion reference is one of the cohesive devices. The result shows that endophoric reference exists in Mark Zuckerberg biography endophoric. Endophoric consist of two types, the first is anaphoric and the second is cataphoric. In this research there are five type cohesive devices that are usually used in texts like substitution, references, ellipsis, lexical cohesion, and conjunctions. In the research found that cataphoric is dominant than anaphoric because the subject is located in the beginning of the sentences. Cohesive devices not only focused on lexical cohesion, but also focused on ellipsis and substitution and reference.
\end{abstract}

Keywords: Discourse Analysis, Reference, Endophoric, Pragmatic

\section{INTRODUCTION}

Discourse analysis is a multidisciplinary approach. It focuses on the study of language in use, including the two modes the written and the spoken one. These two modes are different in their features such as grammar, lexis, and situation. Z. Harris $(1951,1952)$ in (Abbamonte, Cavaliere, $\&$ Porta, 2017), discourse analysis refers to efforts to examine the arrangement of language above clauses and sentences, and therefore also to study broader units of language. Like conversation or written languages. Consequently, discourse analysis also pays attention to language when it is used in a social context, especially interactions between speakers. Therefor discourse analysis is essentially a study of language functions or the use of language as a means of communication.

Cohesion is a unit that exists in text and relates the meaning of words. The text said in cohesively written if the sentences consist of cohesive devices. According to Halliday \& Hasan (1976) as cited (Hidayat, 2017) in the form of grammatical cohesive device there are consist of five lexical cohesion, reference, conjunction, substitution and ellipsis

Reference closely related to the description of meaning as an element in the sign system, it can be seen that there are two basic elements in a sign system that directly have a relationship with meaning (Ridwan, 2015). Reference is one type of grammatical cohesion or is a particular 
lingual unit that refers to another lingual unit (or a reference) that precedes or follows it. (Emilia, Habibi, \& Bangga, 2018) reference Identified of an item which introduced through text. There are three types of reference homophobic, exophoric, and endophoric references Eggins (2004). In this research focuses on the endophoric reference.

Endophoric is one of reference type which can be recalled from within a text (Emilia, 2014). Eggins (2004) in (Emilia et al., 2018) state that Endophoric consist of three types: Anaphoric or in other term called as "backward-looking" for example; the teacher asked Ahmad to read the book, therefore he read the book. Cataphoric or recalled as"forward-looking" for example; This animal like to eat a banana, Monkey like it a banana.

The research of an analyzing cohesive devices in written discourse has been finished by some writers. Firstly, Widiane Pande (2016) carried out research entitled "Substitution and Ellipsis in Novel Sweet Frannie By Susan Sallis". This research tried to investigates the kind of reference substitution and ellipsis found in that novel and types of cohesive devices used in that novel. Secondly, Asri (2012) held a study "Reference and its translation in the novel Harry Potter and the chamber of secrets by J.K Rowling". Thirdly, "Lexical Cohesion Used in Indonesian and English Versions of Laskar Pelangi, A Novel" by Luluk (2014), From all of the relevant research before, the previous writers only analyze some parts of cohesive devices. In this research, the writer wants to analyze endophoric reference of cohesive devices that contain in Mark Zuckerberg biography.

\section{METHOD}

The writer only using the data from an article biography of Mark Zuckerberg. In this research, the writer used descriptive qualitative research design. The researcher used a qualitative method because an explanation in this paper is needed. The process of collecting the data from Mark Zuckerberg biography is first the writer tried to find out an article about Mark Zuckerberg biography from the website (Biography.com Editors, 2014). Second, the writer read the article as the data for this research repeatedly. Third, the writer marked the word that consists of endophoric reference. Fourth the writer wrote the endophoric reference words. Fifth, the writer identified the data depend on the type of reference between anaphoric or cataphoric. Sixth, put all of the data in the table then give the explanation.

\section{RESULTS AND DISCUSSION}

Based on the analysis from the article. The writer describes the result through endophoric categorize table, in the Biography, there is 29 Paragraph about a journey's career of Mark Zuckerberg and the writer found some type of endophoric that are Anaphoric and Cataphoric.

Table 1 Categorize the type of Endophoric 


\begin{tabular}{|c|c|c|}
\hline $\begin{array}{l}\text { Type of } \\
\text { Endophoric }\end{array}$ & Sentence Analysis & Explanation \\
\hline Cataphoric & $\begin{array}{l}\text { He left Harvard after his sophomore } \\
\text { year to concentrate on the site, } \\
\text { Zuckerberg become a billionaire. }\end{array}$ & $\begin{array}{l}\text { References he at the end of the sentences } \\
\text { and then the subjects in the beginning. } \\
\text { References he including to pronoun that } \\
\text { can describe the subject (Zuckerberg) of } \\
\text { the text. }\end{array}$ \\
\hline Cataphoric & $\begin{array}{l}\text { His father, Edward Zuckerberg, ran } \\
\text { a dental practice } \\
\text { His mother, Karen, worked as a } \\
\text { psychiatrist before the birth. }\end{array}$ & $\begin{array}{l}\text { References his refers to (Edward } \\
\text { Zuckerberg), the subject located in the } \\
\text { beginning of the. } \\
\text { References his refers to (Karen), the } \\
\text { subject located in the beginning of the. }\end{array}$ \\
\hline Anaphoric & $\begin{array}{l}\text { Zuckerberg developed an interest in } \\
\text { computers at an early age; when he } \\
\text { was about } 12\end{array}$ & $\begin{array}{l}\text { References he at the end of the sentences } \\
\text { and then the subjects in the beginning. } \\
\text { References he including to pronoun that } \\
\text { can describe the subject (Zuckerberg) of } \\
\text { the text. }\end{array}$ \\
\hline Anaphoric & $\begin{array}{l}\text { Because of Mark's burgeoning } \\
\text { interest in computers, his parents } \\
\text { called a tutor }\end{array}$ & $\begin{array}{l}\text { References his at the end of the sentences } \\
\text { and then the subjects in the beginning. } \\
\text { References he including to pronoun that } \\
\text { can describe the subject (Mark's) of the } \\
\text { text. }\end{array}$ \\
\hline Anaphoric & $\begin{array}{l}\text { Zuckerberg study later in Philips } \\
\text { Exeter Academy, an exclusive } \\
\text { preparatory school in New } \\
\text { Hampshire. }\end{array}$ & $\begin{array}{l}\text { References an refers to (philip Exeter } \\
\text { Academy), the subject located at the end } \\
\text { of the sentences. } \\
\text { References his at the end of the sentences } \\
\text { and then the subjects in the beginning. } \\
\text { References he including to article that can } \\
\text { describe the subject (Zuckerberg) of the } \\
\text { text. }\end{array}$ \\
\hline
\end{tabular}




\begin{tabular}{|c|c|c|}
\hline Cataphoric & $\begin{array}{l}\text { After his sophomore year, } \\
\text { Zuckerberg dropped out of college } \\
\text { to devote himself to Facebook full } \\
\text { time. }\end{array}$ & $\begin{array}{l}\text { References his at the beginning of the } \\
\text { sentences and then the subjects in the end. } \\
\text { References he including to article that can } \\
\text { describe the subject } \\
\text { (Zuckerberg) of the text. }\end{array}$ \\
\hline Cataphoric & $\begin{array}{l}\text { The Harvard creator claimed that } \\
\text { Zuckerberg stole their idea and } \\
\text { insisted the software developer } \\
\text { needed to pay for their business } \\
\text { losses. }\end{array}$ & $\begin{array}{l}\text { References their refers to (the Harvard } \\
\text { creator), the subject located at the end of } \\
\text { the sentences. }\end{array}$ \\
\hline Cataphoric & $\begin{array}{l}\text { Since amassing his sizeable fortune, } \\
\text { Zuckerberg has used his millions to } \\
\text { fund a variety of philanthropic } \\
\text { causes. }\end{array}$ & $\begin{array}{l}\text { References his at the beginning of the } \\
\text { sentences and then the subjects in the end. } \\
\text { References his including to pronouns that } \\
\text { can describe the subject (Zuckerberg) of } \\
\text { the text. }\end{array}$ \\
\hline Anaphoric & $\begin{array}{l}\text { How Zuckerberg's company will } \\
\text { handle this influx of cash remains to } \\
\text { be seen. }\end{array}$ & $\begin{array}{l}\text { References this at the end of the sentences } \\
\text { and then the subjects in the beginning. } \\
\text { References this including to } \\
\text { Demonstrative that can describe the } \\
\text { subject (Zuckerberg) of the text. }\end{array}$ \\
\hline Cataphoric & $\begin{array}{l}\text { The Facebook stock price dropped, } \\
\text { Zuckerberg is expected that his } \\
\text { company can developed the } \\
\text { performance }\end{array}$ & $\begin{array}{l}\text { References at the beginning of the } \\
\text { sentences and then the subjects in the } \\
\text { beginning. References The including to } \\
\text { article that can describe the subject } \\
\text { (Zuckerberg) of the text. }\end{array}$ \\
\hline Anaphoric & $\begin{array}{l}\text { Zuckerberg and Chan announced } \\
\text { on Facebook that they were } \\
\text { expecting their second child. }\end{array}$ & $\begin{array}{l}\text { References they at the end of the } \\
\text { sentences and then the subjects in the } \\
\text { beginning. References they including to } \\
\text { article that can describe the subject (Mark } \\
\text { and Chan) of the text. }\end{array}$ \\
\hline
\end{tabular}

Based on the result in table 1 the type of endophoric above that Mark Zuckerberg Biography anaphoric and cataphoric is exist in every paragraph. Then, the pattern of Endophoric (anaphoric and cataphoric) not only in Discourse Analysis but in Pragmatic also that is references and inferences.

\section{CONCLUSION}


Based on the finding and discussion, the research shows that the endophoric reference exists and found in every paragraph. Then, the Endophoric (anaphoric and cataphoric) not only found in Discourse Analysis but in Pragmatic also exist there are references and inferences. Therefore the relationship between discourse analysis and pragmatic both of them are focuses on the form of the language and context used, while discourse analyze at cohesion, coherence and pragmatics looking for response (perlocutionary) and functional purpose (illocutionary) elements of the language used. Therefore both of them are related each other especially in communication. Pragmatic and discourse becoming part of each another since both of them are focused on the context, language used and how the context influence the meaning in communication.

\section{ACKNOWLEDGMENTS}

The writer would like to thank Allah the Almighty, who has given me mercy and blessings. The pleasure to work during this and other related projects also the writer would like to thank for Cynantia Rahmijati,M.M.Pd as the journal supervisor in order making this journal better than before

\section{REFERENCES}

Abbamonte, L., Cavaliere, F., \& Porta, V. (2017). Discourse Analysis and Pragmatics: Their scope and relation., 21(1), 105-125. https://doi.org/10.22363/2312

Biography.com Editors. (2014). Mark Zuckerberg Biography.

Emilia, E., Habibi, N., \& Bangga, L. A. (2018). an Analysis of Cohesion of Exposition Texts: an Indonesian Context. Indonesian Journal of Applied Linguistics, 7(3), 515. https://doi.org/10.17509/ijal.v7i3.9791

Hidayat, A. (2017). An Analysis of Grammatical Cohesive Device of the Short Story the Little Match Girl by Hans Christian Andersen. English Education: Jurnal Tadris Bahasa Inggris, 9(2), 232-244.

Ridwan, M. (2015). Kohesi Referensi Teks Arab. Jurnal CMES, V I I I, 1-10. 